\title{
BRPKM
}

Buletin Riset Psikologi dan Kesehatan Mental

http://e-journal.unair.ac.id/index.php/BRPKM

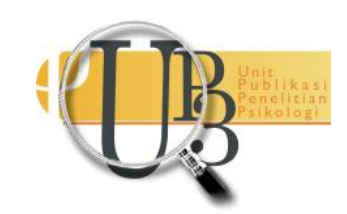

LAPORAN KASUS

\section{Modifikasi Perilaku untuk Meningkatkan Kepatuhan Minum Obat pada Pasien Skizofrenia}

AFIFAH NURAINI*

Departemen Psikologi Klinis dan Kesehatan Mental, Fakultas Psikologi Universitas Airlangga

\begin{abstract}
ABSTRAK
Tujuan dari penelitian ini adalah untuk mengetahui efektivitas modifikasi perilaku untuk meningkatkan kepatuhan minum obat pada pasien skizofrenia. Partisipan dalam penelitian ini berjumlah satu orang, yaitu seorang wanita berusia 40 tahun yang mengalami skizofrenia. Penelitian ini merupakan penelitian single case experimental design. Instrument pada penelitian ini berupa lembar observasi dan wawancara berdasarkan DSM IV-TR. Analisis data yang diperoleh menggunakan analisis deskriptif untuk menjelaskan perubahan perilaku yang ditunjukkan partisipan sebelum dan setelah pemberian intervensi. Hasil penelitian ini menunjukkan bahwa terdapat perubahan peningkatan kepatuhan minum obat yang ditandai dengan jadwal minum obat dan dosis yang sesuai dengan anjuran dokter ketika diberikan modifikasi perilaku. Dengan demikian, dapat disimpulkan bahwa modifikasi perilaku efektif untuk meningkatkan kepatuhan minum obat pada penderita skizofrenia.
\end{abstract}

Kata kunci: modifikasi perilaku, perilaku minum obat, skizofrenia

\begin{abstract}
The aim of this study was to determine the effectiveness of behavioral modification to improve medication adherence in schizophrenia. The participant in this study was a 40-years-old woman who was diagnosed with schizophrenia. This research was a single case experimental design. The measurement strategy in this research was employing an observation sheet and interview based on DSM IV-TR. Analysis data using descriptive analysis to explain the behavioral changes shown participant before and after intervention. The result of this study indicates that there are positive changes in the adherence of taking medication and according to the dosage of the participant after behavior modification. Therefore, it can be concluded that the behavioral modification is effective to improve medication adherence in schizophrenia.
\end{abstract}

Keywords: behavioral modification, medication adherence, schizophrenia

Buletin Penelitian Psikologi dan Kesehatan Mental (BRPKM), 2021, Vol. 1(1), 1-10

*Alamat korespondensi: Fakultas Psikologi Universitas Airlangga, Kampus B Universitas Airlangga Jalan

Airlangga 4-6 Surabaya 60286. Surel: nurul.hartini@psikologi.unair.ac.id

Naskah ini merupakan naskah dengan akses terbuka dibawah ketentuan the Creative Common Attribution License (CC-BY-4.0) (http://creativecommons.org/licenses/by/4.0), sehingga penggunaan, distribusi, reproduksi dalam media apapun atas artikel ini tidak dibatasi, selama sumber aslinya disitir dengan baik. 


\section{P E N D A H U L U A N}

Skizofrenia merupakan gangguan psikotik yang ditandai dengan gangguan dalam pikiran, emosi, dan perilaku. Gangguan pada pikiran terjadi dengan berbagai pemikiran yang tidak saling berhubungan secara logis, persepsi dan perhatian yang salah, afek datar atau tidak sesuai, dan berbagai gangguan aktivitas motorik yang aneh (bizarre) (Davison, Neale, \& Kring, 2014). Gangguan skizofrenia biasa menyerang jati diri individu dengan memutus hubungan antara pikiran dan perasaan kemudian mengisinya dengan persepsi yang salah serta ide dan konsep yang tidak logis (Nevid, Rathus, \& Grene, 2003). Eugen Bleuler menjelaskan bahwa karakteristik utama dari gangguan skizofrenia adalah terpisahnya fungsi otak yang mempengaruhi proses kognisi, respon perasaan atau afektif, dan tingkah laku. Selanjutnya ia juga menjabarkan bahwa gangguan skizofrenia dapat dikenali berdasarkan empat gejala atau simtom primer, yaitu; asosiasi atau hubungan antar pikiran yang terganggu, afek atau respon emosional yang datar atau tidak sesuai, ambivalen atau perasaan konfilk terhadap orang lain, dan autism atau menarik diri ke dunia fantasi pribadi yang tidak terikat oleh prinsip logika (Nevid, Rathus, \& Grene, 2003).

Pada beberapa kasus skizofrenia terjadi penurunan perlahan dan berangsur pada fungsi individu. Periode kemunduran ini disebut sebagai fase prodomal (prodomal phase) yang ditandai dengan berkurangnya minat dalam aktivitas sosial dan meningkatnya kesulitan dalam memenuhi tanggung jawab di kehidupan sehari-hari, seperti melakukan aktivitas sehari-hari dan bekerja. Setelah fase tersebut, seseorang dengan skizofrenia memasuki fase residual (residual phase) yang ditandai dengan kembalinya perilaku mereka pada tingkat sebelum fase prodomal (Nevid, Rathus, \& Grene, 2003).

Davison, Neale, \& Kring (2014) dalam bukunya menjelaskan lima (5) kategori yang menjadi tipe utama dari gangguan skizofrenia, yaitu; Tipe 1 atau Simtom positif yang biasa ditandai dengan hal-hal yang berlebihan dan distorsi seperti halusinasi dan delusi atau waham; Tipe 2 atau Simtom negatif yang biasanya ditandai dengan berkurangnya atau hilangnya fungsi-fungsi normal seperti ekspresi emosi, tingkat motivasi rendah, hilangnya kesenangan pada aktivitas tertentu, menarik diri secara sosial, dan berkurangnya komunikasi; Tipe Disorganisasi yang ditandai dengan berkurangnya kemampuan berbicara dan menunjukkan perilaku aneh (bizarre); Tipe Katatonik yang ditandai dengan abnormalitas dalam kemampuan motorik seperti melakukan gerakan berulang kali, lengan seringkali seperti menunjuk tujuan tertentu, dan menunjukkan postur yang tidak biasa dan menetap dalam waktu yang sangat lama; dan terakhir adalah Tipe Paranoid yang biasanya ditandai dengan satu atau lebih waham atau terdapat halusinasi auditoris.

Berdasarkan temuan kasus, diketahui partisipan berinisial UH berusia 40 tahun. Kemudian peneliti melakukan pendampingan selama beberapa waktu serta observasi dan wawancara secara berkala dengan berdasar pada DSM IV-TR, peneliti menemukan bahwa partisipan mengalami gangguan skizofrenia undifferentiated. Hal tersebut ditandai dengan delusi yaitu selalu dihampiri oleh anak kecil, halusinasi auditoris, menunjukkan cara bicara yang inkoheren, dan berpenampilan tidak sesuai usianya yaitu dengan menunjukkan penampilan seperti anak berusia sekitar 10 tahun. Hasil asesmen menunjukkan adanya ketidaksesuaian antara realitas dengan pemikiran partisipan. Terdapat pula tanda kecemasan yang dimunculkan partisipan melalui hasil grafis yang dibuatnya. Tanda kecemasan tersebut didukung oleh tes TAT yang menunjukkan bahwa partisipan banyak mengangkat tema mengenai perselisihan dalam keluarga, baik antara suami-istri maupun orangtua dan anak. Kebutuhan yang muncul berkaitan dengan keinginan partisipan untuk mendominasi, melawan, menjalin relasi dengan orang lain, dan mencari ketenangan.

Kondisi yang dialami partisipan telah berlangsung sejak usia remaja. Pada awal kondisi, lingkungan sekitar dan keluarga meyakini bahwa partisipan sedang kerasukan atau diikuti oleh sosok anak-anak, oleh sebab itu perilaku dan penampilan yang ditunjukkan partisipan seolah dirinya merupakan anakBuletin Riset Psikologi dan Kesehatan Mental (BRPKM) 2021 Vol. 1(1), 1-10 
anak. Kemudian pihak kesehatan menyarankan untuk membawa partisipan melakukan cek kesehatan di rumah sakit. Partisipan kini menjalani pengobatan dengan tidak rutin meminum obat yang diberikan dokter dan tidak pernah mendatangi dokter untuk melakukan kontrol. Ibu partisipan menjelaskan jika sejak partisipan mulai bekerja selama 1 tahun ini, ibunya yang selalu mendatangi dokter ke rumah sakit untuk menjelaskan kondisi partisipan dan meminta resep obat. Hal tersebut kerena partisipan tidak ingin upah bekerjanya dipotong karena ijin. Ibu partisipan menambahkan bahwa obat yang selama ini ditebus tidak dikonsumsi secara rutin oleh partisipan, sehingga tidak jarang obat tersebut rusak dan tidak layak konsumsi karena terlalu lama. Obat baru yang diberikan oleh dokter akan menjadi stok dan baru digunakan jika obat yang lama sangat rusak dan tidak dapat dikonsumsi.

Banyak penelitian menunjukkan bahwa obat-obatan antipsokotik efektif untuk mengobati gejala skizofrenia (Thornley \& Adams, 1998; Zygmunt, Olfson, Boyer, \& Mechanic, 2000). Obat-obatan antipsikotik bertujuan untuk mengurangi gejala-gejala yang muncul dan dirasakan oleh penderita skizofrenia. Berdasarkan karakteristik partisipan, partisipan meyakini bahwa obat-obatan yang harus di konsumsi merupakan vitamin untuk kesehatan dan dengan obat tersebut ia menjadi lebih mudah tidur dengan nyenyak di malam hari dan meredakan sakit kepala. Namun partisipan mengakui jika dirinya tidak suka mengkonsumsi obat tersebut terus menerus karena merasa dirinya sehat dan tidak pusing. Pernyataan tersebut sejalan dengan penjelasan (Phan, 2016) yang menyebutkan bahwa pasien skizofrenia yang menghadapi penyakitnya dengan mengabaikan gejala atau berpura-pura sehat memiliki kecenderungan untuk tidak mematuhi pengobatan, sebaliknya pasien skizofrenia yang dapat menerima penyakitnya dan memiliki strategi koping yang lebih positif cenderung lebih patuh terhadap pengobatan. (Hawari, 2016) menambahkan, penyebab ketidakpatuhan pasien skizofrenia dalam mengkonsumsi obat adalah karena proses pengobatan yang membutuhkan waktu lama menimbulkan kejenuhan pada pasien, sehingga menurunkan kepatuhan pasien untuk mengkonsumsi obat.

Disisi lain, ketidakpatuhan minum obat yang dilakukan oleh pasien skizofrenia dapat memberikan dampak negatif terhadap diri pasien. Keluarga partisipan menjelaskan jika partispan tidak rutin minum obat maka partisipan akan menunjukkan perilaku seperti sebelumnya, seperti mudah tersinggung, marah dengan meluap-luap, diam mematung dengan pandangan kosong, dan tidak dapat tidur dengan tenang. Situasi tersebut membuat aktivitas bekerja partisipan serta lingkungan kerja merasa terganggu. Pernyataan tersebut sejalan dengan penjelasan (Zygmunt, Olfson, Boyer, \& Mechnic, 2002) yang menyatakan bahwa ketidakpatuhan dalam konsumsi obat pada pasien skizofrenia dapat meningkatkan resiko kekambuhan. Kekambuhan karena ketidakpatuhan minum obat juga dapat menimbulkan konsekuensi yang lebih mengganggu seperti peningkatan potensi menyerang atau perilaku berbahaya, terutama pada periode psikosis. Ketidakpatuhan dalam pengobatan berdampak negatif pada perjalanan penyakit yang dapat mengakibatkan kekambuhan, kembali ke rumah sakit, prognosis yang buruk, hingga percobaan bunuh diri (Leucht \& Heres, 2006; Higashi, et al., 2013). Episode psikosis atau kekambuhan yang berulang dapat menyebabkan perkembangan psikosis kronis, waktu perbaikan gejala yang lama dan kemungkinan resisten terhadap obat antispikotik (Phan, 2016). Lebih lanjut, kekambuhan yang berulang juga dapat menyebabkan peningkatan gangguan fungsional hingga kecacatan (Haddad, Brain, \& Scott, 2014). Konsekuensi lain dari ketidakpatuhan pengobatan pada penderita skizofrenia dapat mengakibatkan resiko peningkatan penggunaan zat sebagai komorbid, penurunan fungsi kognitif, penurunan kualitas hidup, peningkatan agresivitas, peningkatan perilaku kekerasan, hingga beresiko bunuh diri (Haddad, Brain, \& Scott, 2014; Phan, 2016).

Salah satu pendekatan yang dapat dilakukan pada pasien skizofrenia adalah konseling keluarga dan intervensi perilaku atau behavioral therapy. Behavioral therapy atau terapi perilaku merupakan terapi yang menerapkan beberapa teknik dan prosedur yang berdasar pada teori belajar. Behavioral therapy menekankan pada penerapan sistematis dalam prinsip-prinsip belajar dengan tujuan mengubah perilaku kearah yang lebih adaptif (Corey, 2007). Dasar dari behavioral therapy dan modifikasi perilaku

Buletin Riset Psikologi dan Kesehatan Mental (BRPKM)

2021 Vol. 1(1), 1-10 
adalah teori belajar, sehingga aspek penting yang ditekankan adalah perilaku yang didefinisikan secara operasional, dapat diamati, dan diukur. Perubahan perilaku merupakan kriteria spesifik yang dapat dievaluasi sesuai dengan tujuan proses terapeutik (Corey, 2007). Teknik modifikasi perilaku yang dilakukan pada penelitian ini berasal dari teori belajar operant conditioning yang dikembangkan oleh B.F. Skinner. Skinner memiliki pandangan bahwa konsekuensi dapat mempertahankan perilaku, dalam hal ini reinforce atau penguat merupakan konsekuensi yang meningkatkan kemungkinan terjadinya perilaku yang diinginkan. Token ekonomi merupakan salah satu bentuk penguat positif, sehingga partisipan dapat menerima satu token ketika mereka memperlihatkan perilaku yang diinginkan. Selanjutnya token akan diakumulasi dalam jumlah tertentu dan dapat ditukarkan dengan reward (Erford, 2015).

Beberapa penelitian membahas penerapan modifikasi perilaku pada pasien skizofrenia, seperti yang dilakukan oleh (Dickerson, Tenhula, \& Paden, 2004) yang membahas mengenai penerapan token ekonomi pada pasien skizofrenia, menjelaskan bahwa penerapan token ekonomi secara kelompok efektif untuk meningkatkan perilaku adaptif pada pasien skizofrenia. Sejalan dengan hasil penelitian tersebut, penelitian yang dilakukan oleh Gholipour, Abolghasemi, Gholinia, \& Taheri (2012) yang membahas mengenai efektivitas token reinforcement dan olahraga untuk menurunkan simtom negatif pada pasien skizofrenia menjelaskan bahwa terapi token memiliki efektifitas lebih tinggi dibandingkan terapi olahraga untuk menurunkan gejala atau simtom negatif yang muncul pada pasien skizofrenia. Penelitian lain yang dilakukan oleh (Sari, 2016) mengenai penerapan modifikasi perilaku berupa reward dan punishment untuk meningkatkan perilaku rutin minum obat pada pasien skizofrenia. Hasil penelitian tersebut menunjukkan bahwa reward dan punishment efektif untuk merubah perilaku pasien menjadi lebih rutin minum obat, meminta sendiri obatnya di jam minum obat, dan meminta untuk ditemani ketika melakukan kontrol ke dokter.

Berdasarkan efektivitas modifikasi perilaku dengan token ekonomi pada pasien skizofrenia, peneliti tertarik untuk melihat dampak modifikasi perilaku dengan token ekonomi dalam meningkatkan kepatuhan minum obat pasien skizofrenia. Dengan demikian, tujuan dari penelitian ini adalah untuk mengetahui efektivitas modifikasi perilaku dengan token ekonomi untuk meningkatkan kepatuhan minum obat pada pasien skizofrenia.

\section{Partisipan Penelitian}

\section{MET O D E}

Partisipan dalam penelitian ini adalah seorang perempuan berusia 40 tahun, memiliki seorang anak laki-laki berusia 7 tahun, suami pertisipan telah meninggal dunia sekitar 5 tahun yang lalu. Saat ini partisipan dan anaknya tinggal dengan orangtua partisipan di wilayah Rangkah, Surabaya. Partisipan telah didiagnosa mengalami skizofrenia dan menjalani pengobatan di rumah sakit sejak usia 18 tahun. Desain penelitian yang digunakan dalam penelitian ini merupakan single case experiment design. Penelitian ini merupakan penelitian eksperimen studi kasus dengan memahami kasus yang akan diteliti secara lebih mendalam.

\section{Instrumen Penelitian}

Instrumen penelitian yang digunakan dalam penelitian ini berupa lembar observasi dan wawancara yang mengacu pada simtom atau gejala skizofrenia berdasarkan DSM IV-TR. Penilaian dilakukan dalam tiga tahapan yaitu sebelum diberikan intervensi dan dua lainnya dalam proses intervensi. Penelitian ini juga menggunakan alat eksperimen berupa panduan program intervensi modifikasi perilaku yang telah disusun oleh peneliti berdasarkan karakteristik partisipan. 


\section{Prosedur Intervensi}

Sesi intervensi disusun berdasarkan modifikasi perilaku dengan teknik token ekonomi yang dikembangkan B.F Skinner. Intervensi ini terdiri dari psikoedukasi yang ditujukan untuk keluarga partisipan, identifikasi perilaku partisipan yang ingin diubah, membuat dan menampilkan aturan, serta menetapkan nilai yang ingin ditukar. Berikut adalah gambaran dari masing-masing sesi intervensi;

a. Sesi 1: Psikoedukasi. Pada sesi ini dilaukan psikoedukasi pada keluarga partisipan untuk memahami tujuan dan prosedur intervensi serta pentingnya komitmen dalam menentukan keberhasilan intevensi. Selain itu, diberikan pula pemahaman dan gambaran mengenai kondisi partisipan pada keluarga.

b. Sesi 2: Identifikasi perilaku yang ingin diubah dan aturan token ekonomi. Pada sesi ini peneliti, partisipan dan keluarga bersama-sama mengidentifikasi perilaku yang ingin diubah dengan lebih jelas dan spesifik. Pada sesi ini juga, bersama-sama menentukan peraturan yang jelas serta menetapkan nilai token dan reward yang ingin ditukarkan.

c. Sesi 3: Pemberian aturan token. Pada sesi ini diberikan dan dijelaskan ulang mengenai aturan yang berlaku dan form token yang harus diisikan ketika perilaku yang diinginkan muncul.

d. Sesi 4: Penukaran poin token dan evaluasi. Pada sesi ini dilakukan penukaran poin token yang terkumpul dengan reward, serta mengevaluasi perubahan yang dialami partisipan selama perilaku yang diinginkan muncul dan diperkuat.

e. Sesi 5: Penukaran poin token, evaluasi, dan terminasi. Pada sesi ini dilakukan kembali penukaran poin token yang terkumpul dengan reward, serta evaluasi perubahan yang dialami dan dirasakan partisipan dan keluarga selama perilaku yang diinginkan muncul dan diperkuat. Pada sesi ini terjadi terminasi atau akhir sesi intervensi, dimana selanjutnya dapat diteruskan oleh keluarga untuk memperkuat perilaku yang diinginkan.

\section{Teknik Analisis Data}

Teknik analisis data yang digunakan dalam penelitian ini merupakan teknik analisis deskriptif dengan membandingkan perilaku partisipan sebelum dan setelah pemberian intervensi dengan modifikasi erilaku.

\section{HAS IL PENELITIAN}

Intervensi yang diberikan pada partisipan merupakan metode modifikasi perilaku untuk meningkatkan kepatuhan minum obat partisipan. Target perilaku dalam intervensi ini adalah meningkatkan rutinitas minum obat partisipan sesuai dosis dan resep yang diberikan dokter. Peneliti bekerjasama dengan keluarga partisipan untuk mencatat peningkatan rutinitas minum obat partisipan di rumah sesuai dengan dosis dan waktu minum obat partisipan. Selain itu, peneliti juga meminta orangtua partisipan untuk memantau perubahan yang dialami partisipan. Berikut hasil observasi yang dilakukan peneliti dan keluarga terhadap rutinitas minum obat partisipan sebelum pemberian intervensi. 
Tabel 1. Hasil Observasi Rutinitas Minum Obat Partisipan Sebelum Intervensi

\begin{tabular}{|c|c|c|c|}
\hline \multirow{2}{*}{ Jadwal dan Obat } & \multicolumn{3}{|c|}{ Pertemuan } \\
\hline & $\mathrm{H}_{1}$ & $\mathrm{H}_{2}$ & $\mathbf{H}_{3}$ \\
\hline \multirow{2}{*}{ Pagi } & $\sqrt{ }$ & $\sqrt{ }$ & $\sqrt{ }$ \\
\hline & $\sqrt{ }$ & $\sqrt{ }$ & $\sqrt{ }$ \\
\hline \multirow{3}{*}{ Malam } & & & $\sqrt{ }$ \\
\hline & & & $\sqrt{ }$ \\
\hline & & & $\sqrt{ }$ \\
\hline Keterangan & Diminum siang hari & $\begin{array}{l}\text { Diminum sore hari dan } \\
\text { tidak sesuai dosis }\end{array}$ & Sesuai \\
\hline
\end{tabular}

\section{Sesi 1: Psikoedukasi}

Hasil dari sesi ini adalah keluarga mampu memahami kondisi dan keterbatasan yang dimiliki partisipan. Keluarga menyadari bahwa partisipan sering melalaikan kewajibannya dalam minum obat sehingga perlu diingatkan dan diperhatikan. Selain itu keluarga juga mampu memahami mengenai keterbatasan partisipan dalam komunikasi dan menangkap maksud dari sebuah percakapan, sehingga perlu kesabaran dan bimbingan untuk memberikan informasi pada partisipan. Keluarga juga bersedia berkomitmen dan kooperatif selama pelaksanaan proses inervensi.

\section{Sesi 2: Identifikasi Perilaku dan Aturan Token}

Hasil dari sesi ini partisipan dan keluarga mampu mengidektifikasi perilaku yang ingin diubah dengan lebih spesifik dan jelas. Perilaku yang ingin diubah adalah perilaku minum obat dengan rutin sesuai jadwal dan dosis yang diberikan dokter. Keluarga juga diberikan pemahaman pengenai penggunaan token sebagai salah satu cara untuk memperkuat kemunculan perilaku yang ingin diubah dari partisipan.

\section{Sesi 3: Pemberian Aturan Token}

Hasil dari sesi ini adalah keluarga mampu memahami prosedur dan aturan dari proses penggunaan token. Sehingga selanjutnya keluarga dapat berperan untuk menuliskan poin ketika perilaku minum obat sesuai jadwal dan dosis dimunculkan oleh partisipan. Prosedur minum obat partisipan disesuaikan dengan jadwal dan dosis yang diberikan oleh dokter serta mengikuti kegiatan partisipan sehari-hari. Seperti diketahui partisipan bekerja di salah satu pabrik plastik di wilayah Rangkah, sehingga prosedur minum obat disesuaikan dengan jam kerja partisipan. Berikut adalah prosedur yang disepakati berkaitan dengan jadwal dan dosis minum obat yang akan dilakukan oleh partisipan;

Tabel 2. Prosedur Minum Obat Partisipan

\begin{tabular}{ccc}
\hline Waktu & Nama Obat & 8jDosis \\
\hline Pagi & Anemolat & 1 tablet \\
\cline { 2 - 3 } Pukul 06.15 & Trifluoperazin & $1 / 2$ tablet \\
\hline Malam & Trifluoperazin & 1 tablet \\
\cline { 2 - 3 } Pukul 19.00 & Depakote & 1 tablet \\
\cline { 2 - 3 } (setelah makan malam sebelum tidur) & Clozapine & 1 tablet \\
\hline
\end{tabular}

Sesi 4: Penukaran Poin dan Evaluasi

Hasil dari sesi ini adalah partisipan dapat menunjukkan peningkatan rutinitas minum obat dan kesesuaian dengan jadwal serta dosis yang diberikan oleh dokter. Pada sesi ini juga dilakukan evaluasi Buletin Riset Psikologi dan Kesehatan Mental (BRPKM) 2021 Vol. 1(1), 1-10 
dari pihak partisipan maupun keluarga. Keluarga menjelaskan bahwa sejauh ini partisipan mulai rutin untuk kembali minum obat meskipun sesekali harus diingatkan namun partisipan melakukannya segera dan tidak menunda. Sejalan dengan pernyataan tersebut, partisipan pun menyatakan jika saat ini dirinya selalu minum obat setiap pagi sebelum berangkat bekerja dan malam sebelum tidur. Partisipan menambahkan perubahan yang dirasakan setelah rutin minum obat selama seminggu ini adalah tidak lagi merasa pusing-pusing dan dapat tidur lebih nyenyak. Hal tersebut serupa dengan penjelasan keluarga bahwa setelah rutin minum obat, sikap dan perilaku partisipan menjadi lebih tenang dan terkontrol, partisipan tidak mudah marah dan tersinggung serta tidak sering melamum. Berikut adalah evaluasi perilaku kepatuhan minum obat partisipan pada minggu pertama;

Tabel 3. Evaluasi Perilaku Kepatuhan Minum Obat Partisipan di Minggu Pertama

\begin{tabular}{ccccccccc}
\hline \multirow{2}{*}{ Jadwal } & \multicolumn{10}{c}{ Hari } & \multirow{2}{*}{ Total Poin } \\
\cline { 2 - 7 } & Sabtu & Minggu & Senin & Selasa & Rabu & Kamis & Jumat & \\
\hline Pagi & $\sqrt{ }$ & $\sqrt{ }$ & $\sqrt{ }$ & $\sqrt{ }$ & $\sqrt{ }$ & $\sqrt{ }$ & $\sqrt{ }$ & 7 \\
\hline Malam & $\sqrt{ }$ & $\sqrt{ }$ & $\sqrt{ }$ & $\sqrt{ }$ & $\sqrt{ }$ & $\sqrt{ }$ & & 6 \\
\hline
\end{tabular}

Sesi 5: Penukaran Poin, Evaluasi, dan Terminasi

Hasil dari sesi ini adalah partisipan menunjukkan konsistensi peningkatan rutinitas minum obat seduai jadwal dan dosis yang diberikan dokter seperti perilaku yang dimunculkan pada minggu sebelumnya. Keluarga partisipan menjelaskan jika partisipan mulai cukup terbiasa untuk rutin minum obat karena ingin mengumpulkan poin dan mendapatkan hadiah seperti minggu sebelumnya. Keluarga menambahkan, setelah rutin minum obat selama dua minggu terakhir perilaku partisipan menjadi lebih terkontrol dan lebih tenang. Hal tersebut membuat keluarga merasa senang dan bangga pada partisipan. Pada sesi ini juga menjadi akhir dari sesi intervensi yang dilakukan peneliti. Meskipun tidak dalam pendampingan peneliti, diharapkan keluarga bersedia meneruskan cara yang digunakan oleh peneliti untuk memperkuat perilaku minum obat partisipan. Berikut adalah evaluasi perilaku kepatuhan minum obat partisipan pada minggu kedua;

Tabel 4. Evaluasi Perilaku Kepatuhan Minum Obat Partisipan di Minggu Kedua

\begin{tabular}{cccccccccc}
\hline \multirow{2}{*}{ Jadwal } & \multicolumn{7}{c}{ Hari } & \multirow{2}{*}{ Total Poin } \\
\cline { 2 - 8 } & Sabtu & Minggu & Senin & Selasa & Rabu & Kamis & Jumat & \\
\hline Pagi & $\sqrt{ }$ & $\sqrt{ }$ & $\sqrt{ }$ & $\sqrt{ }$ & $\sqrt{ }$ & $\sqrt{ }$ & $\sqrt{ }$ & 7 \\
\hline Malam & $\sqrt{ }$ & $\sqrt{ }$ & $\sqrt{ }$ & $\sqrt{ }$ & $\sqrt{ }$ & $\sqrt{ }$ & & 6 \\
\hline
\end{tabular}

\section{I S K U S I}

Berdasarkan hasil asesmen diketahui bahwa partisipan mengalami skizofrenia undifferentiated yang ditandai dengan delusi seolah dihampiri anak kecil, halusinasi auditoris, menunjukkan cara bicara yang inkoheren, dan berpenampilan tidak sesuai dengan usianya yaitu menunjukkan penampilan seperti anak berusia sekitar 10 tahun. Hasil tersebut didukung oleh penegakan diagnosis berdasarkan gejala atau simtom skizofrenia pada DSM IV-TR yang menunjukkan bahwa beberapa kriteria diagnostik dari gejala skizofrenia ditunjukkan oleh partisipan, seperti delusi, halusinasi, pembicaraan tidak koheren, asosiasi longgar, perilaku tidak terorganisir atau katatonik, afek datar, kegagalan dalam melakukan perawatan diri dengan baik, gejala yang terus menerus terjadi selama lebih dari 6 bulan.

Kondisi yang dialami partisipan telah berlangsung sejak partisipan berusia remaja. Proses pengobatan yang dijalani partisipan saat ini adalah melakukan rawat jalan dengan dokter di salah satu rumah sakit Buletin Riset Psikologi dan Kesehatan Mental (BRPKM)

2021 Vol. 1(1), 1-10 
pemerintah di Surabaya. Namun selama kurang lebih satu tahun, partisipan tidak pernah lagi berkunjung ke dokter untuk melakukan kontrol, hanya ibu partisipan yang datang menemui dokter untuk menceritakan kondisi partisipan dan meminta resep obat. Obat yang diberikan oleh dokter pun tidak rutin dikonsumsi oleh partisipan, tidak jarang partisipan meminum obat lama yang masih ada dengan kondisi yang rusak dan tidak layak konsumsi. Obat yang dikonsumsi partisipan pun seringnya tidak sesuai dengan dosis yang diberikan oleh dokter. Dengan ketidakpatuhan minum obat yang dialami partisipan membuat proses pengobatan partisipan menjadi tidak tuntas. Keluarga partisipan menjelaskan jika partisipan tidak rutin mengkonsumsi obat, makan ia akan menunjukkan perilaku seperti mudah tersinggung, kemarahan yang meluap-luap, sering melamun bahkan mematung, dan mengalami halusinasi auditoris. (Zygmunt, Olfson, Boyer, \& Mechnic, 2002) menjelaskan bahwa ketidakpatuhan dalam konsumsi obat pada pasien skizofrenia dapat meningkatkan resiko kekambuhan. Selain itu, konsekuensi lain dari ketidakpatuhan minum obat pada pasien skizofrenia dapat mengakibatkan resiko peningkatan penggunaan zat sebagai komorbid, penurunan fungsi kognitif, penurunan kualitas hidup, peningkatan agresivitas, peningkatan perilaku kekerasan, hingga beresiko bunuh diri (Haddad, Brain, \& Scott, 2014) (Phan, 2016).

Modifikasi perilaku diberikan pada partisipan untuk meningkatkan kepatuhan minum obat. Proses intervensi dengan modifikasi perilaku pada partisipan berlangsung sejak tanggal 29 Desember 2016 sampai 20 Januari 2017. Selama proses modifikasi perilaku dengan token ekonomi, terdapat peningkatan kepatuhan minum obat yang ditunjukkan oleh partisipan. Partisipan pun merasakan perubahan dalam dirinya karena telah patuh mengkonsumsi obat sesuai jadwal dan dosis yang diberikan dokter. Partisipan menyatakan jika dirinya tidak merasa pusing dan tidur lebih nyenyak. Sejalan dengan hal tersebut, keluarga partisipan mengungkapkan kondisi partisipan setelah rutin mengkonsumsi obat sesuai jadwal dan dosis dokter adalah menjadi lebih tenang dan terkontrol, tidak mudah marah, serta tidak lagi sering melalun atau mematung. Hal tersebut sejalan dengan penelitian sebelumnya yang dilakukan oleh (Dickerson, Tenhula, \& Paden, 2004) bahwa penerapan token ekonomi dapat meningkatkan perilaku adaptif pada pasien skizofrenia. Serta mendukung penelitian yang dilakukan (Sari, 2016) bahwa reward dapat merubah perilaku minum obat pasien skizofrenia menjadi lebih rutin.

Follow-up dilakukan sekitar satu bulan setelah proses intervensi berakhir. Dari hasil follow-up menunjukkan bahwa terjadi penurunan perilaku kepatuhan minum obat dari partisipan. Menurut keluarga, hal tersebut karena keluarga memiliki kesibukan masing-masing sehingga tidak selalu dapat mengingatkan partisipan untuk minum obat. Sedangkan partisipan menyatakan jika dirinya lupa untuk minum obat. Hal tersebut sesuai dengan penjelasan (Phan, 2016) mengenai faktor yang mengakibatkan ketidakpatuhan minum obat pada pasien skizofrenia yang antara lain disebabkan oleh kurangnya wawasan atau kesadaran, psikopatologi, stigma, permasalahan yang berkaitan dengan perawatan atau caregiver pasien, persepsi dan sikap pasien terhadap penyakit dan minum obat, pengaruh budaya, dan status sosial ekonomi.

\section{S I M P U L A N}

Berdasarkan hasil analisis secara deskriptif, dapat disimpulkan bahwa modifikasi perilaku dapat meningkatkan kepatuhan minum obat pada penderita skizofrenia. Pada penelitian ini, setelah pemberian intervensi selama dua minggu partisipan menunjukkan peningkatan rutinitas minum obat sesuai dengan jadwal dan dosis yang dianjurkan dokter. Meskipun setelah dilakukan follow-up sekitar satu bulan setelah intervensi, terjadi penurunan perilaku kepatuhan dari partisipan. 
Peneliti selanjutnya dapat mengembangkan penelitian serupa dengan menambahkan intervensi berupa konseling keluarga yang ditujukan pada keluarga pasien. Hal tersebut diharapkan mendukung efektivitas intervensi dengan mempertahankan konsistensi penerapan intervensi dari pihak keluarga. Selain itu, peneliti selanjutnya juga dapat memperbanyak sampel atau partisipan penelitian sehingga hasil penelitian dapat digeneralisasikan pada tingkat populasi yang lebih luas.

\section{U C A P A N T ER IMAKASIH}

Dengan selesainya penulisan ini saya ingin berterima kasih kepada seluruh pihak yang membantu dan mendukung saya dalam penulisan jurnal ini terutama dosen pembimbing saya Ibu Nurul Hartini yang selalu memberikan motivasi dan semangat dan juga orang tua saya yang mendukung dari awal sampai akhir serta teman teman terbaik saya yang selalu penuh mendukung disetiap harinya, saya ucapkan banyak terima kasih.

\section{DEKLARASI POTENSI TERJADINYA KONFLIK KEPENTINGAN}

Afifah Nuraini tidak bekerja, menjadi konsultan, memiliki saham, atau menerima dana dari perusahaan atau organisasimanapun yang mungkin akan mengambil untung dari diterbitkannya naskah ini.

\section{PUSTAKA ACUAN}

American Psychiatric Assosiation. (2000). Diagnostic and Statistical Manual of Mental Disorders Fourth Edition Text Revision, DSM-IV-TR. Arlington, VA: American Psychiatric Association.

Corey, G. (2007). Teori dan Pratek Konseling dan Psikoterapi. Terj. Bandung: Refika Aditama.

Davison, G. C., Neale, J. M., \& Kring, A. M. (2014). Psikologi Abnormal. 9th Ed. terjemahan. Jakarta: Rajawali Pers.

Dickerson, F., Tenhula, W., \& Paden, L. (2004). The Token Economy for Schizofrenia: Review of the Literature and Recommendations for Future Research. Schizophrenia Research, 75(2), 405-416. Doi: 10.1016/j.schres.2004.08.026.

Erford, B. T. (2015). 40 Techniques Every Counselor Should Know. Terj. 2nd Ed. Yogyakarta: Pustaka Pelajar.

Gholipour, A., Abolghasemi, S., Gholinia, K., \& Taheri, S. (2012). Token Reinforcement Therapeutic Approach is More Effective than Exercise for Controlling Negative Symptoms of Schizophrenic Patients. International Journal of Perventive Medicine, 3(7), 466-470.

Haddad, P., Brain, C., \& Scott, J. (2014). Nonadherence with Antipsychotic Medication in Schizophrenia: Challenges and Management Strategies. Patient Related Outcomes Measures, 5(1), 43-62. Doi: 10.2147/PROM.S42735.

Hawari, D. (2016). Pendekatan Holistik Pada Gangguan Jiwa: Skizofrenia. Jakarta: Balai Penerbit FKUI.

Higashi, K., Medic, G., Littlewood, K., Diez, T., Granstrom, O., \& Hert, M. (2013). Medication Adherence in Schizophrenia: Factos Influencing Adherence and Consequences of Nonadherence. Therapeutic Advance in Psychoparmacology, 3(4), 200-218. Doi: 10.1177/ 2045125312474019.

Buletin Riset Psikologi dan Kesehatan Mental (BRPKM)

2021 Vol. 1(1), 1-10




Nevid, J. D., Rathus, S. A., \& Grene, B. (2003). Psikologi Abnormal. 5th Ed. terjemahan. Jakarta: Erlangga.

Phan, S. (2016). Medication Adherence in Patients with Schizophrenia. The International Journal of Psychiatry in Medicine, 51(2), 211-219. Doi: 10.1177/0091217416636601.

Sari, G. (2016). Penerapan Reward dan Punishment untuk Meningkatkan Perilaku Rutin Minum Obat pada Pasien Skizofrenia. Psychology Forum UMM.

Zygmunt, A., Olfson, M., Boyer, C., \& Mechnic, D. (2002). Interventions to Improve Medication Adherence in Schizophrenia. American Journal Psychiatry, 159(10), 1653-1664. Doi: 10.1176/appi.ajp.159.10.1653. 